\title{
The Impact of Cucumber (Cucumissativus) Juice on Blood Pressure in Elderly With Hypertension
}

\section{Dinda Evania, Budi Punjastuti*, Pritta Yunitasarí, and Siti Maryati}

D-III Nursing Study Program, Karya Husada Health Polytechnic, Yogyakarta

\section{ORCID}

Budi Punjastuti: https://orcid.org/0000-0001-9632-3696

\begin{abstract}
Hypertension is a type of degenerative disease. Blood pressure increases slowly with age. In 2018, the prevalence of hypertension in people aged 65-74 years in Indonesia was $57.6 \%$ and in those over 75 years was $63.8 \%$. Cucumber juice is a natural product that may be useful for lowering blood pressure without side effects because its potassium content may help improve blood flow and calm nerves so that blood pressure drops. This study aimed to analyze the effectiveness of cucumber juice in reducing blood pressure in elderly people with hypertension. This was a literature review. Articles were obtained using Google Scholar, PubMed and Lipi, with the keywords: hypertension, cucumber juice, elderly. 435 articles were screened and five were identified for the review. Based on the results of these studies, it was found that there was a significant decrease in blood pressure after the elderly were given cucumber juice and this decrease was as much as 100-200 mg per day. We can therefore conclude that cucumber juice can be effective in lowering blood pressure in elderly people with hypertension. These findings can be applied in daily life.
\end{abstract}

Corresponding Author: Budi Punjastuti; email:

budipunjas123@gmail.com

Published: 7 February 2022

Publishing services provided by Knowledge E

(c) Dinda Evania et al. This article is distributed under the terms of the Creative Commons

Attribution License, which permits unrestricted use and redistribution provided that the original author and source are credited.

Selection and Peer-review under the responsibility of the IVCN Conference Committee.

\section{G OPEN ACCESS}

Keywords: hypertension, cucumber juice, elderly

\section{Introduction}

Hypertension is a continuous increase in systolic or diastolic blood pressure. Generally, the systolic blood pressure reaches $140 \mathrm{mmHg}$ or more and the diastolic blood pressure is $90 \mathrm{mmHg}$, this have indicates pre-hypertension. Blood pressure increases slowly with age. According to World Health Organization (WHO) in 2015 showed around 1.13 billion people in the world suffer from hypertension, which means that 1 in 3 people in the world has hypertension [1]. The results of the 2018 Basic Health Research (Riskesdas) show that the prevalence of hypertension in the population in Indonesia over the age of 18 is $34.1 \%$. Hypertension occurs in the age group 31-44 years (31.6\%), age $45-54$ years (45.3\%), age 55-64 years (55.2\%), 65-74 years old (57.6\%) and more than 75 years old (63.8\%). While the data in the Special Region of Yogyakarta according to the Indonesian Ministry of Health in 2019 the most hypertension sufferers were in Bantul 
Regency, which was 38,641 patients, with the elderly with hypertension as many as 1,174 people.

Treatment of hypertension, in general can be done by pharmacological and nonpharmacological treatment. Pharmacological treatment is treatment using antihypertensive drugs to lower blood pressure. Non-pharmacological treatment is treatment without drugs, by changing a healthier lifestyle and avoiding risk factors. [2]

Non-pharmacological treatment is by modifying daily lifestyles. Non-pharmacological therapy in lowering blood pressure uses natural resources, namely fruits, vegetables that are high in fiber, rich in vitamins and minerals. [3]

Fruits and vegetables that are efficacious in lowering high blood pressure include celery, cucumber, chayote, watercress, radish, tomatoes, starfruit, sweet star fruit, watermelon, carrots, bananas, apples, and kiwis.

Cucumber is one of the fruit vegetables that is very well known and quite in demand by the public. Cucumbers are also cultivated everywhere, whether in fields, yards, or greenhouses. Cucumber (Cucumis sativus) is quite popular in almost all countries, including Indonesia. In Indonesia, cucumbers are widely grown in Java and Sumatra. Many Indonesians like to consume cucumbers, usually for fresh vegetables, made into pickles, vegetable salads, and also consumed as fresh drinks such as juice.

In the journal from Eva Marvia, et al (2018), Cucumber contains saponins (removes mucus), protein, fat, calcium, potassium, magnesium, phosphorus, iron, sulfur, vitamins A, $B 1$, and C. In regulating blood pressure is potassium / potassium. Potassium/potassium content can increase the concentration in intracellular fluid so that blood pressure drops, so it tends to draw fluid from the extracellular part and lowers blood pressure due to the vasodilating effect of blood vessels, potassium is the main ion in the intracellular fluid which works the opposite of sodium/salt. And also cucumber can lower blood pressure without any side effects. [4]

Based on the description of the background of the problem above, cucumber juice is verry important because it can lowering blood pressure without side effect so it's safe to useespecially in elderly, so the authors are interested in conducting a case study with a literature review on the effectiveness of cucumber juice (Cucumis sativus) in reducing blood pressure in the elderly with hypertension. 


\section{Method}

\subsection{Design}

This research is a research using literature study method or literature review. A literature review is a broad overview of the research that has been done on a specific topic. The type of literature review that used in this study is the traditional literature review. Traditional literature review is a method commonly carried out by researchers, and we can find many results in existing survey papers. The reviewed scientific papers are selected by the researchers themselves on a research topic and are selected based on the knowledge and experience of a researcher [5]. And choose the study with Quasy Eksperimen design with Pre and Post-Test.

In conducting this study, the authors searched for research journals published on the internet using Google Schoolar, Pubmed, and Lipi, with the keywords: Hypertension, Cucumber Juice, Elderly. The inclusion criteria of the journals to be reviewed are research journals with elderly subjects with hypertension level 1 and 2 according to JNC-VII data with the theme of giving cucumber juice to people with hypertension, full text is available with a journal publication period of 2011-2020 and exclusion criteria are subjects who are not elderly, themes other than giving cucumber juice to hypertension sufferers, full text is not available, published under 2011 and above 2020.

\subsection{Sample}

The research sample used in the five journals is $40 \%$ using Non-Probability Sampling ( At $1^{\text {st }}$ and $2^{\text {nd }}$ study) and the remaining $20 \%$ using Total Sampling ( $4^{\text {th }}$ study), Simple Random Sampling ( $3^{\text {rd }}$ study), and Purposive Sampling ( $5^{\text {th }}$ study). And the subjects are elderly with hypertension level 1 and level 2 .

\subsection{Data Analysis}

Research journals that match the inclusion criteria are collected. A journal summary is made, including the researcher's name, year of publication, journal publisher, research location (City or State), objectives, methods, samples, and summary of results or findings. Then to further clarify the analysis of the abstract and full text of the journal, read and observe. The summary of the journal is then analyzed on the contents contained in the 
research objectives and research results. The analytical method used is the contents of analysis of each journal.[6].

\section{Result}

Based on search results through Google Scholar, Pubmed, and Lipi, with the keywords: Hypertension, Cucumber Juice, Elderly. The author finds journals that match these keywords. A total of 435 journals from journals found according to these keywords were screened. A total of 233 journals were excluded because full text articles were not available. Of the 25 full text journals, they were screened again based on predetermined inclusion criteria. And as many as 20 journals were excluded, so that 5 fulltext journals were reviewed.

The five journals reviewed found significant differences between blood pressure before and after being given cucumber juice. The first study conducted by Mardiati Barus, et al. (2019) respondents were given 100 grams of cucumber juice for 7 days. The Wilcoxon Test result $\mathrm{p}<\mathrm{a}(0.001<0.05)$ for systolic and diastolic pressures, which means that there is a significant difference between blood pressure before and after treatment. With data on the difference in blood pressure before and after the intervention, the systolic blood pressure before the intervention was $149.13 \mathrm{mmHg}$ and the systolic pressure after the intervention was $136.09 \mathrm{mmHg}$. With these results, the systolic pressure decreased by $13.04 \mathrm{mmHg}$. And for diastolic blood pressure before intervention was $97,83 \mathrm{mmHg}$ and diastolic pressure after intervention of $86.96 \mathrm{mmHg}$. With these results, the diastolic pressure decreased by $10.87 \mathrm{mmHg}$ [7].

The second study conducted by Candra Kusuma, et al (2018) found that the average systolic blood pressure before treatment was $149.68 \mathrm{mmHg}$, with the lowest systolic blood pressure being $140 \mathrm{mmHg}$ and the highest $160 \mathrm{mmHg}$. Before treatment, the average diastolic blood pressure was $95.88 \mathrm{mmHg}$ with the lowest diastolic pressure of $90 \mathrm{mmHg}$ and the highest $105 \mathrm{mmHg}$. While the average systolic blood pressure after treatment was $136.65 \mathrm{mmHg}$, with a decrease of $13.03 \mathrm{mmHg}$. The average for diastolic blood pressure after treatment was $89.08 \mathrm{mmHg}$ with a decrease of $6.8 \mathrm{mmHg}$. Respondents were given cucumber juice treatment with a composition of 200 grams of cucumber with $100 \mathrm{ml}$ of water, which was given for 3 days in the morning at 09.00 WITA [8].

The third study conducted by Sumirah Budi, et al (2017) found that systolic blood pressure was around $150 \mathrm{mmHg}$, had diastolic blood pressure around $90 \mathrm{mmHg}$. 
After being given treatment, the most systolic blood pressure was $150 \mathrm{mmHg}$, and the diastolic blood pressure was at most $90 \mathrm{mmHg}$. And after averaging the systolic pressure from $164.86 \mathrm{mmHg}$ to $148.43 \mathrm{mmHg}$ with a decrease of $16.49 \mathrm{mmHg}$, and the diastolic blood pressure from $97.29 \mathrm{mmHg}$ to $87.63 \mathrm{mmHg}$ with a decrease of 9.66 $\mathrm{mmHg}$. Respondents were given cucumber juice treatment with a composition of 100 grams of cucumber and $200 \mathrm{ml}$ of water, and consumed for one week a day 2 times in the morning and evening with the same dose. And the results obtained P-Value value $0.000<0.05$ which indicates a significant effect of cucumber juice [9].

The fourth study conducted by Sariaman Purba (2019) obtained the results of the analysis of the effect of cucumber juice (cucumis sativus linn) on reducing blood pressure in hypertensive patients in Sindang Barang, it was known that the significant value was 0.000 or $\mathrm{P}$ value $<0.05$. Which means there is a significant difference between blood pressure before and after treatment. The systolic blood pressure before treatment was $163 \mathrm{mmHg}$ to $149 \mathrm{mmHg}$ with a decrease of $14 \mathrm{mmHg}$ and the diastolic blood pressure before treatment was $98 \mathrm{mmHg}$ to $93 \mathrm{mmHg}$ with a decrease of $5 \mathrm{mmHg}$ [3].

The fifth study conducted by Sri Lestari, et al (2015) found that systolic pressure decreased by $34 \mathrm{mmHg}$. The average systolic blood pressure measurement before the intervention was $165.33 \mathrm{mmHg}$ and the systolic pressure after the intervention was $131.33 \mathrm{mmHg}$. While the diastolic pressure decreased by $4.67 \mathrm{mmHg}$. The average diastolic blood pressure measurement before the intervention was $98.00 \mathrm{mmHg}$ and the diastolic pressure after the intervention was $95.33 \mathrm{mmHg}$. Respondents were given $100 \mathrm{cc}$ of cucumber juice given for 3 times (once a day for 3 days) [10].

\section{Discussion}

The results of the analysis from 5 journal carried out that the examination of blood pressure in the elderly before giving cucumber juice was an average of more than $149.13 \mathrm{mmHg}$, for systolic blood pressure and for the average diastolic blood pressure more than $97.83 \mathrm{mmHg}$ respectively. These data are supported by data from JNC-VII (2013), and with this data is hypertension level 1, namely from 140-159 mm Hg for systolic blood pressure and $90-99 \mathrm{mmHg}$ for diastolic, as well as level 2 hypertension with systolic $160 \mathrm{mmHg}$ and diastolic $100 \mathrm{~mm} \mathrm{Hg}$.

From the results of the analysis of blood pressure before the intervention, it proves that the older a person is, the greater the risk of developing hypertension. (Prof. Suhadjono, 2018) 
This can happen because in old age there is narrowing and stiffness of blood vessels caused by changes in the structure of blood vessels, as a result of increased systolic blood pressure. With increasing age it will increase the average diastolic blood pressure, although it does not have much effect on the increase in the prevalence of hypertension for each decade of age. (Sartik, et al, 2017)

In old age, the walls of the arteries have thickened and stiffened due to arteriosclerosis. Blood with each heartbeat is forced to pass through vessels that are narrower than usual and cause pressure to rise [8].

However, after giving cucumber juice to the elderly with hypertension as much as 100200 grams per day, will decrease systolic blood pressure of $13-34 \mathrm{mmHg}$ and decrease the diastolic blood pressure of $4-10,87 \mathrm{mmHg}$.

With the results of lowering blood pressure above, it is proven that cucumber juice can reduce blood pressure effectively. Cucumber juice is one of the recommended non-pharmacological treatments for hypertension sufferers. In addition to the potassium/potassium content in cucumbers which can lower blood pressure, there is also a magnesium mineral which also plays a role in improving blood flow and calming nerves and relaxing the heart muscle so that blood pressure drops. (Kholish, 2011). In addition, according to Khomsan (2017) that high consumption of calcium, magnesium and fiber contained in vegetables such as cucumbers can reduce systolic and diastolic blood pressure by $5.5 \mathrm{mmHg}$ and $3 \mathrm{mmHg}$, respectively.

In line with research conducted by Ni Made Dwi (2017), et al., respondents were given treatment with $\pm 200 \mathrm{ml}$ of cucumber juice given for 5 days, the results showed that systolic blood pressure decreased by $9.33 \mathrm{mmHg}$ and diastolic blood pressure decreased by $3.33 \mathrm{mmHg}$.

From the discussion above, it can be concluded that the elderly (elderly) have a higher risk of developing hypertension, due to increasingly stiff blood vessels. Consuming cucumbers that are processed in the form of juice is one of the non-pharmacological techniques without side effects that can be used by the public to lower blood pressure. By giving 100-200 ml of cucumber juice per day, it can effectively lower blood pressure in hypertensive elderly. Materials that are easily available and simple manufacturing methods can be utilized by the community well. 


\section{References}

[1] Kemenkes RI. Infodatin pusat data dan informasi kementerian kesehatan RI. Jakarta: Kemenkes; 2017.

[2] Anjani, N. D., Sulendri, N. S., Laraeni, Y., \& Jaya, I. S.. Pengaruh pemberian jus mentimun air kelapa muda terhadap penurunan tekanan darah lansia hipertensi di panti sosial tresna werdha 'Puspakarma' mataram. 2017.

[3] Purba S. Pengaruh pemberian jus mentimun (Cucumis sativus linn) terhadap penurunan tekanan darah pada pasien hipertensi di kelurahan sindang barang kota bogor. Bogor Jurnal IImiah Wijaya. 2019;11:2301-4113.

[4] Marvia, E. Efektifitas pemberian jus mentimun dan semangka terhadap penurunan tekanan darah pada penderita hipertensi di dusun al-liqok wilayah kerja puskesmas korleko lombok timur. 2018. PrimA: Jurnal IImiah IImu Kesehatan.

[5] Poltekkes Soepraoen. BAB 2 konsep review ilmiah. Malang repository poltekkessoepraoen.

[6] Barus M, Ginting A, Turnip AJ. Studi ners STIKes santa elisabeth medan. Terapi jus mentimun menurunkan tekanan darah pada penderita hipertensi 1. 2019.

[7] Kusuma Negara C, Erna E, Anna A. The effect of cucumber juice (Cucumis sativus) toward hypertension of elderly at tresna werdha budi sejahtera social institution of Banjarbaru South Borneo 2017. Indonesian Journal of Nursing Practice. 2018;2(1). doi: 10.18196/ijnp.2174

[8] Pertami SB, Rahayu DYS, Budiono B. Effect Of cucumber (Cucumis sativus) juice on lowering blood pressure in elderly. Public Health of Indonesia. 2017;3(1):30-36. doi: 10.36685/phi.v3i1.93

[9] Lestari S, Nuraeni DS. Pengaruh pemberian jus mentimun terhadap penurunan tekanan darah lansia hipertensi. Jurnal Kesehatan. 2020;6(1):654-659. doi: 10.38165/jk.v6i1.144 